\title{
Penerapan Metode Profile Matching Dalam Pengembangan Aplikasi E-Commerce Pada Penjualan Barang Elektronik.
}

\author{
Masitoh ${ }^{1}$, Akip Suhendar ${ }^{2}$ \\ 1, Program Studi Sistem Informasi \\ ${ }^{2}$ Program Studi Teknik Informatika \\ Fakultas Teknologi Informasi - Universitas Serang Raya \\ 1 itohblaufunf@gmail.com \\ 2 akip.suhendar@gmail.com
}

\begin{abstract}
Toko Sinar Makmur merupakan salah satu toko yang berbisnis dalam bidang penjualan barang elektronik, sebagai toko yang bergerak dibidang penjualan dirasa perlu adanya sebuah aplikasi online (e-commerce) untuk membantu memperluas jangkauan penjualan dan untuk mengatasi keraguan konsumen dalam membeli secara online, perlu adanya pembuatan sistem pendukung konsumen untuk membantu konsumen dalam melakukan pembelian online dan dapat menentukan pilihan barang yang tepat. Dalam pembuatan sistem pendukung konsumen untuk pembelian barang elektronik secara online ini, metode pengumpulan data yang digunakan terdiri dari wawancara, observasi lapangan, tinjauan kepustakaan. Analisis sistem dan desain sistem dengan menggunakan diagram yang terkandung dalam UML (Unified Modelling Language) serta menggunakan metode Profile matching. Profile matching merupakan proses membandingkan antara nilai aktual dari sebuah barang elektronik dengan nilai sebuah barang elektronik yang diharapkan. Berdasarkan hasil pengembangan aplikasi e-commerce ini sehingga dapat di peroleh barang yang memiliki nilai lebih besar antara barang yang satu dengan barang yang lainnya dan barang yang memiliki nilai lebih besar tersebut akan di rekomendasikan kepada konsumen.
\end{abstract}

Kata kunci : E-Coomerce, Pembelian Online, Profile matching

\section{PENDAHULUAN}

Saat ini banyak orang yang memanfaatkan internet sebagai media pemasaran dan bisnis. Praktik e-commerce dan e-bisnis dinilai mempunyai banyak keuntungan baik bagi perusahaan ataupun konsumen karena internet bisa diakses di mana saja dan kapan saja. Pemanfaatan layanan pembelian melalui internet, selain menghadirkan banyak keuntungan bagi pemasar, juga menghadirkan banyak keuntungan bagi konsumen online.

Sinar Makmur merupakan salah satu toko yang berbisnis dalam bidang penjualan barang elektronik. Sebagai toko yang bergerak di bidang bisnis dirasa perlu suatu sistem pendukung konsumen untuk pembelian barang secara online guna membantu dan memperlancar penyebaran bisnis toko Sinar Makmur, dan dapat memberikan informasi produk yang ada di toko Sinar Makmur terhadap konsumen serta dapat memudahkan konsumen dalam melakukan pembelian online dan dapat menentukan pilihan barang yang diinginkan.

Sistem pendukung konsumen sebagai alternatif penunjang keputusan pihak toko yang dapat digunakan untuk memberikan rekomendasi bagi konsumen baik bagi calon pembeli barang elektronik maupun konsumen yang hanya mencari informasi.

\subsection{E-Commerce}

E-Commerce merupakan konsep baru yang bisa digambarkan sebagai proses jual beli barang atau jasa di internet. Umumnya transaksi melalui sarana $E$ commerce dilakukan melalui sarana sebuah situs yang diibaratkan sebagai sebuah etalase tempat menjual barang dagangan. Dan dari situs tersebut, para pembeli (customer) dapat melihat bentuk dan spesifikasi produk yang bersangkutan lengkap dengan harga jualnya (Abdul Kadir, $2003: 381$ ).

\subsection{Unified Modelling Language (UML)}

UML (Unified Modeling Language) adalah metode pemodelan secara visual sebagai sarana untuk merancang dan membuat sistem berorientasi objek. Karena UML ini merupakan bahasa visual untuk pemodelan bahasa berorientasi objek, maka semua elemen dan diagram berbasiskan pada paradigma object oriented. (Munawar, 2005: 17-25). 


\subsection{Profile Matching}

Proses pencocokan dengan metode profile matching (GAP) secara garis besar merupakan proses membandingkan antara nilai data aktual dari sebuah barang elektronik yang akan dinilai dengan nilai sebuah barang elektronik yang diharapkan atau nilai sebuah barang yang ideal, sehingga dapat diketahui perbedaan kompetensinya (GAP), semakin kecil GAP yang dihasilkan maka bobot nilainya semakin besar yang berarti memiliki peluang lebih besar untuk direkomendasikan bagi konsumen atau sebagai pendukung konsumen. Proses perhitungan pencocokan profil terdiri dari pemetaan gap, penentuan bobot nilai gap, perhitungan core factor, secondary factor, perhitungan nilai total dan penentuan ranking.

Berikut adalah beberapa tahapan dan perumusan perhitungan dengan metode GAP:

1. Menentukan aspek dan sub aspek penilaian

a. Aspek spesifikasi barang dengan kriteria sub aspek :

1) Merek barang

2) Model barang

3) Type barang

4) Desain barang

b. Aspek kualitas barang dengan kriteria sub aspek :

1) kinerja (Performance)

2) Kemudahan perawatan dan perbaikan (Serviceability)

3) Fitur (Features)

4) Keandalan (Reliability)

5) Tahan lama (Durability)

6) Kecocokan penggunaan (Fitness of use)

7) Kualitas kesesuaian (quality of conformance)

c. Aspek harga barang dengan kriteria sub aspek :
1) Daftar harga
2) Diskon harga
3) Masa berlaku diskon harga

2. Perhitungan pemetaan GAP

Yang dimaksud GAP disini adalah nilai beda antara profil aktual barang elektronik dengan profil barang elektronik yang diharapkan atau dapat dirumuskan sebagai berikut :

GAP $=$ Profil Aktual Barang Elektronik - Profil Barang Elektronik Yang Diharapkan.

3. Pembobotan

Setelah diperoleh GAP masing-masing barang elektronik, setiap barang elektronik di beri bobot nilai dengan patokan yang sudah ditentukan.
4. Perhitungan dan Pengelompokan Core dan Secondary Factor.

Setiap aspek dikelompokkan menjadi 2 kelompok, yaitu core factor dan secondary factor, untuk perhitungan core factor ditunjukan dengan menggunakan rumus dibawah ini :

$\mathrm{NCF}=\frac{\Sigma \mathrm{NC}(\mathrm{sb}, \mathrm{kb}, \mathrm{hb})}{\Sigma \mathrm{IC}}$

Keterangan NCF : nilai rata-rata core factor $\mathrm{NC}$ (sb, $\mathrm{kb}, \mathrm{hg}$ ) : jumlah total nilai core factor (spesifikasi barang, kualitas barang, harga barang) IC : jumlah item core factor

Sedangkan untuk perhitungan secondary factor bisa ditunjukan dengan rumus berikut ini :

$$
\mathrm{NSF}=\frac{\Sigma \mathrm{NS}(\mathrm{sb}, \mathrm{kb}, \mathrm{hg})}{\Sigma \mathrm{IS}}
$$

Keterangan :

NSF : nilai rata-rata secondary factor

$\mathrm{NS}(\mathrm{sb}, \mathrm{kb}, \mathrm{hg}) \quad$ : jumlah total nilai secondary factor (spesifikasi barang, kualitas barang, harga barang)

IS : jumlah item secondary factor

5. Perhitungan Nilai Total

Dari hasil perhitungan setiap aspek diatas, kemudian dihitung nilai total berdasarkan prosentase dari core dan secondary factor yang diperkirakan berpengaruh terhadap kinerja tiap-tiap profil. Contoh perhitungan dapat dilihat pada rumus dibawah ini: $\mathrm{NT}=(\mathrm{X}) \% \mathrm{NCF}(\mathrm{sb}, \mathrm{kb}, \mathrm{hg})+(\mathrm{X}) \% \mathrm{NSF}(\mathrm{sb}, \mathrm{kb}$, hg)

Keterangan :

$\mathrm{NCF}(\mathrm{sb}, \mathrm{kb}, \mathrm{hg}) \quad$ : nilai rata-rata core factor $\mathrm{NSF}(\mathrm{sb}, \mathrm{kb}, \mathrm{hg}) \quad$ : nilai rata-rata secondary factor NT $\quad$ : nilai total dari aspek (X) $\% \quad$ : nilai persen yang dimasukan.

6. Perhitungan Penentuan Ranking

hasil akhir dari proses pencocokan profil (GAP) adalah ranking dari barang elektronik terbaik berdasarkan hasil dari proses penilaian yang akan direkomendasikan bagi konsumen. Penentuan ranking mengacu pada hasil perhitungan rumus dibawah ini :

Ranking $=(\mathrm{X}) \% \mathrm{Nsb}+(\mathrm{X}) \% \mathrm{Nkb}+(\mathrm{X}) \% \mathrm{Nhb}$ 
Keterangan :

Nsb : Nilai spesifikasi barang

$\mathrm{Nkb}$ : Nilai kualitas barang

Nhb: Nilai harga barang

(X) $\% \quad$ :Nilai persen yang dimasukan

\section{METODE PENELITIAN}

Dalam hal menganalisa diawali dengan melakukan pengumpulan data. Data tersebut di analisis dengan menggunakan kerangka PIECES dan akan di olah menggunakan perhitungan metode GAP untuk menentukan barang elektronik yang terbaik dengan nilai lebih besar dari barang yang lainnya. Perancangan sistem ini menggunakan diagram UML (Unified Modelling Language). Salah satu diagram UML dapat dilihat pada gambar dibawah ini.

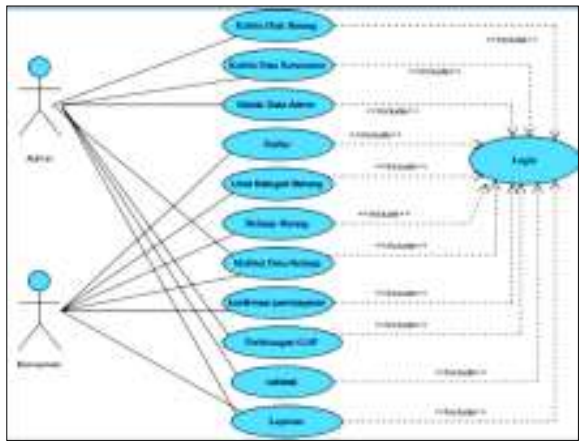

Gambar 3.1 Use Case Diagram

\section{HASIL DAN PEMBAHASAN}

Hasil akhir dari proses Perhitungan GAP secara manual dengan 3 buah data barang elektronik yang berbeda yaitu rangking dari barang elektronik terbaik berdasarkan hasil dari proses penilaian dengan menggunakan teori yang telah dijelaskan pada pembahasan sebelumnya dan yang akan direkomendasikan kepada konsumen maka didapatkan hasil akhir sebagai berikut :

1. Magicom Miyako (001)

2. Magicom Yongma (002)

3. Magicom Cosmos (003)

Table 4.1 Hasil Nilai Akhir Perhitungan Gap

\begin{tabular}{|c|c|c|}
\hline No & Id Barang & Nilai Akhir \\
\hline 1 & 001 & 3,8332 \\
\hline 2 & 002 & 4,00328 \\
\hline 3 & 003 & 3,99656 \\
\hline
\end{tabular}

Pembahasan dari perancangan yang telah dibuat pada sistem pendukung konsumen untuk pembelian barang elektronik secara online dapat dilihat pada gambar berikut ini:
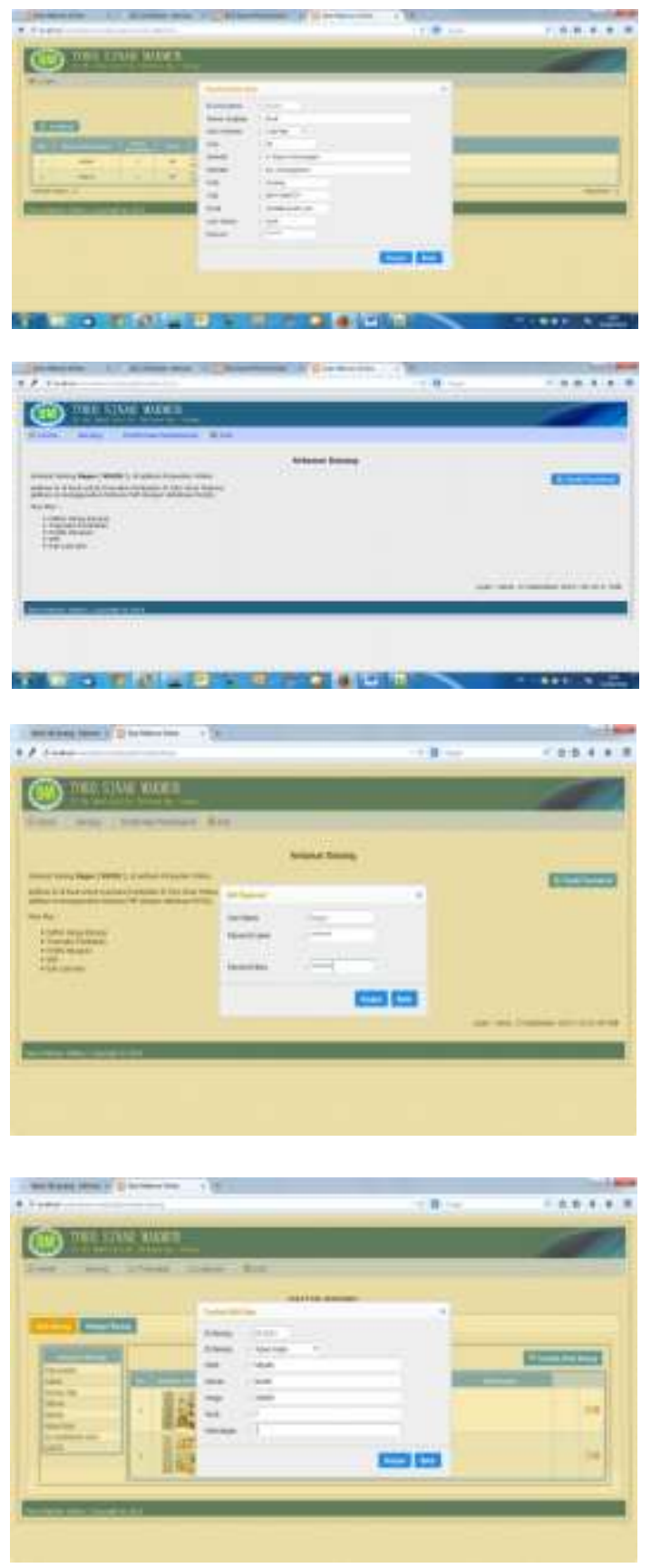

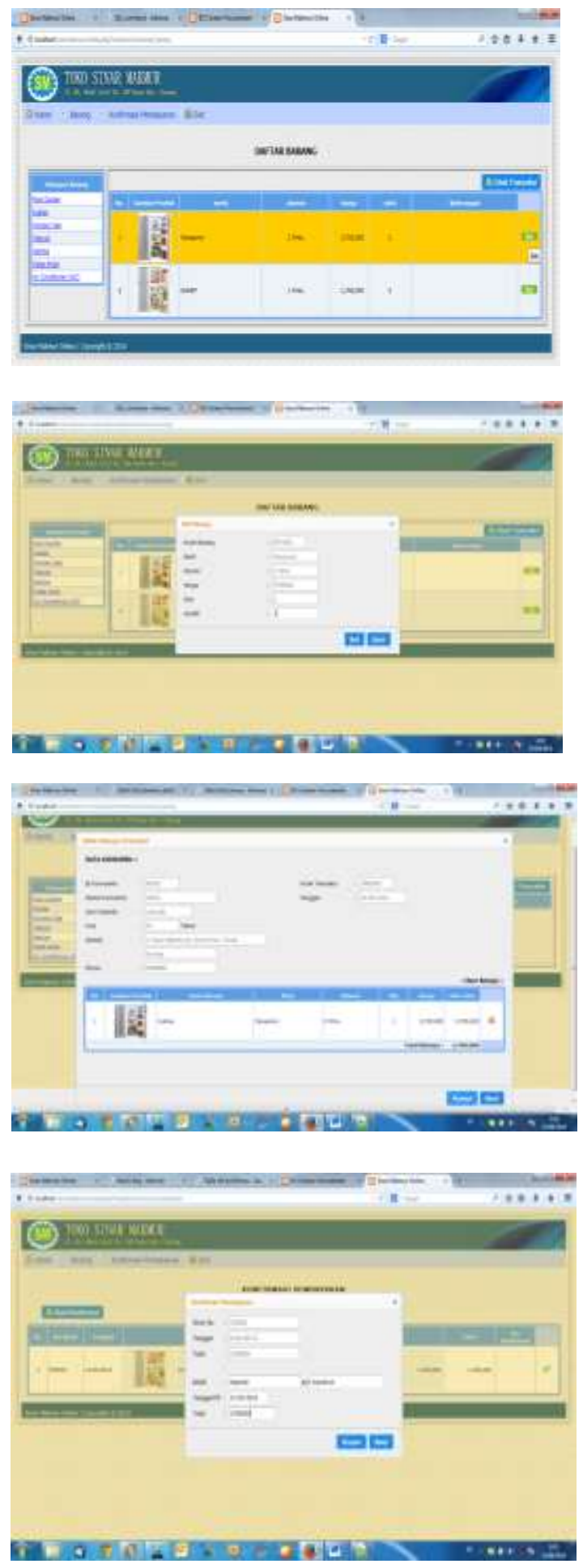
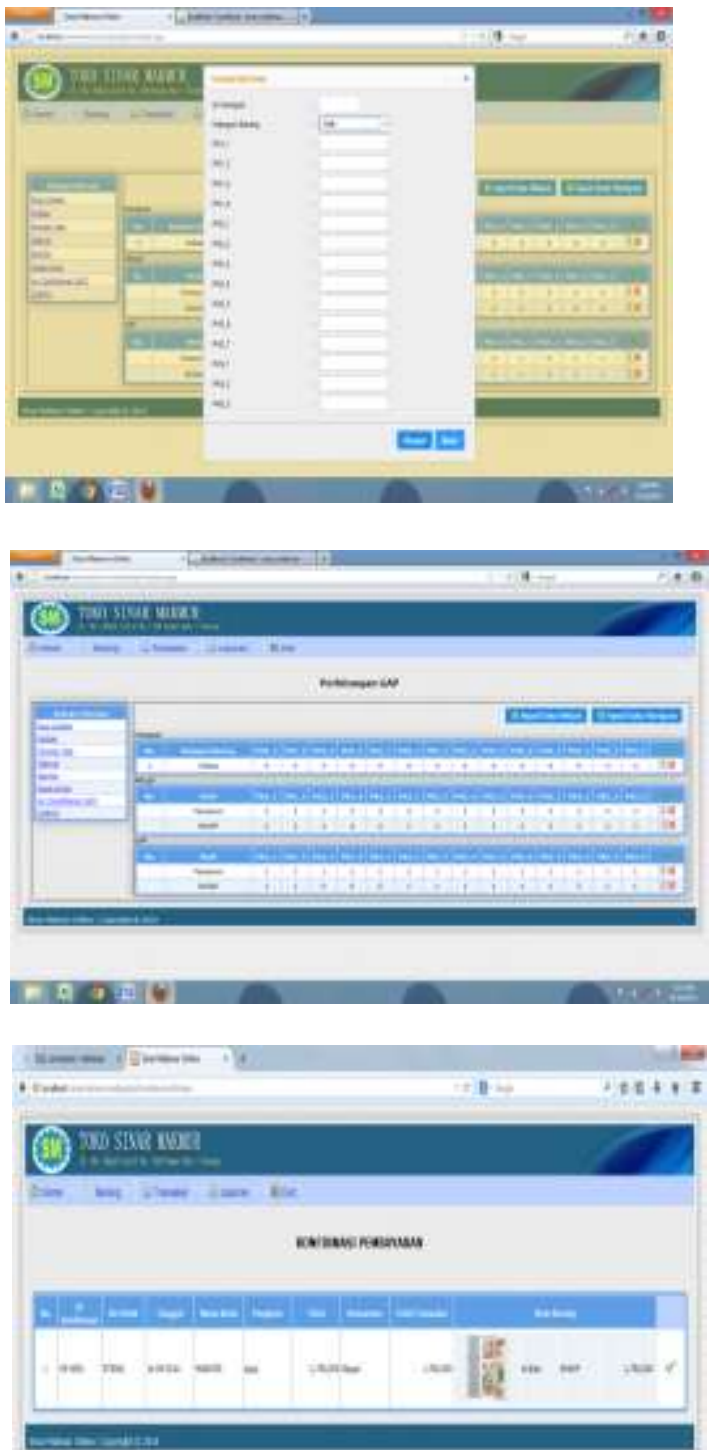

IV. KESIMPULAN

Berdasarkan hasil pembuatan sistem pendukung konsumen untuk pembelian barang elektronik secara online maka dapat diambil kesimpulan yaitu: 
1. Aplikasi ini dapat membantu konsumen memperoleh informasi barang yang dijual dan dapat melakukan pembelian barang elektronik secara online pada toko Sinar Makmur.

2. Aplikasi ini dapat membantu toko Sinar Makmur diantaranya:

a. Dapat memperluas jangkaun penjualan secara online.

b. Untuk mempermudah media penyimpanan data-data penjualan, data konsumen, serta meminimalisir tertukarnya data dan kehilangan data.

c. Keunggulan sistem ini adalah mampu memberikan fleksibilitas bagi pihak toko untuk menentukan data-data privat, yang berupa penentuan nilai core dan secondary factor, penentuan nilai persen, penentuan nilai GAP dan juga penentuan rangking.

\section{REFERENSI}

[1] Albari. (2003). "Mengenal Perilaku Konsumen Mengenai Penelitian Motivasi." Jurnal Siasat Bisnis UII. Vol.1. No.(7). 81-95.

[2] Gantini, Tiur, Deny Kurniawan. (2008). "Website E-Commerce Toko Baros Elektronik Cimahi." Jurnal Sistem Informasi. Vol.3. No. (2). 101-111.

[3] Handojo, Andreas, Djoni H.Setiabudi, Rachma Yunita. (2012) “ Pembuatan Aplikasi sistem Pendukung Keputusan Untuk Proses Kenaikan Jabatan dan Perencanaan Karir Pada PT. X." Journal GAP Umum.

[4] Kadir, Abdul. (2003). Pengenalan Sistem Informasi. Yogyakarta : Andi

[5] Kurniawan, Yahya. (2002). Aplikasi Web Database dengan PHP dan MySql. Jakarta : PT. Elex Media Komputindo

[6] Kusrini. (2007). Konsep dan Aplikasi Sistem Pendukung Keputusan. Yogyakarta : Andi

Moch Suhir, Imam Suyadi, Riyadi. (2014). "Pengaruh Persepsi Resiko, Kemudahan dan Manfaat Terhadap Keputusan Pembelian Secara Online (Survei Terhadap Pengguna Situs Website www.Kaskus.co.id)." Jurnal Administrasi Bisnis (JAB) Vol. 8. No. (1). 1-10.

[7] Munawar. (2005). Pemodelan Visual dengan $U M L$, Edisi Pertama Yogyakarta: Graha Ilmu.
[8] Nugroho, Adi. (2010). Rekayasa perangkat lunak berorientasi objek dengan metode USDP (unified Software Development Process. Yogyakarta : Andi

[9] Pedoman Penulisan Karya Ilmiah. (2014). Serang. Purnastuti, Losina. (2004). "Perdagangan elektronik adalah suatu bentuk pasar yang menjanjikan." Jurnal Ekonomi \& Pendidikan. Vol.1. No. (1) .10-22.

[10] Sadeli, Muhammad. (2011). Membuat Toko Online dengan PHP Untuk Orang Awam. Palembang : Maxikom

[11] Suhari, Yohanes. (2008). "Keputusan Membeli Secara Online dan Faktor-Faktor yang Mempengaruhinya." Jurnal Teknologi Informasi DINAMIK. Vol. XIII. No.(2) . 140-146. 
